\title{
The Impact of Free Trade Domination and Regional Autonomy in the Effectiveness of Act Number 32 of 2009
}

\author{
Raja Al Fath Widya Iswara ${ }^{1}$, Zida Maulina Aini ${ }^{2}$, Agussalim Ali ${ }^{3}$ \\ \{dr.rajaalfath@gmail.com ${ }^{1}$, zidamaulina@gmail.com ${ }^{2}$, agusanestesi0508@gmail.com ${ }^{3}$ \} \\ ${ }^{1}$ Forensic dan Medicolegal Department, Faculty of Medicine, Halu Oleo University, \\ Indonesia \\ ${ }^{2}$ Tropical Medicine Department, Faculty of Medicine, Halu Oleo University, Indonesia \\ ${ }^{3}$ Anestesiology Department, Faculty of Medicine, Halu Oleo University, Indonesia
}

\begin{abstract}
The ASEAN free trade will transform the Southeast Asian region with the free movement of goods, services, investment, skilled labor and capital. The Indonesian government system, in the era of the Regional Autonomy Law (Act No. 32 of 2004), adheres to the school of almost all authority given to the regency/city government, and introduces competition between regency/cities.In Act No. 32 of 2009 concerning Management and Protection of the environment emphasizes the concept of sustainable development to ensure the integrity of the environment as well as the safety, ability, welfare, and quality of life of present and future generations. The dominance of free trade and regional autonomy greatly influences the effectiveness of Act No. 32 of 2009 concerning environmental management and protection.
\end{abstract}

Keywords: Free Trade, Regional Autonomy, Sustainable Development, Act Number 32 of 2009.

\section{Introduction}

The Asia Pacific region is a region that shows rapid economic development in the past decade. At the heart of the Southeast Asia region, there are ten ASEAN countries, which in 2015 will become ASEAN Community, which will be politically cohesive, economically integrated, culturally harmonious and socially responsible [1].

The ASEAN economic community includes extensive cooperation such as human resource development and capacity building, recognition of professional qualifications, close consultation related to macroeconomic and financial policies, trade arrangements, communication connectivity and infrastructure strengthening, electronic transaction development, industrial strengthening in regions that make it possible to advance regional sources, strengthen the private sector as a supporter of the ASEAN economic community [2].

In short, the ASEAN community market will transform this region with the free movement of goods, services, investment, skilled labor and capital flows. With the existence of such integrated markets, Indonesia becomes open in free economic competition and struggle, with countries in the ASEAN region, including gradually with China, South Korea and Japan, within the framework of the AFTA (Asian Free Trade Area) [2].

The Indonesian government system, in the era of the Regional Autonomy Law (Act No 32 of 2004), adheres to the school of law, almost all authority is given to the Regency / City Government, and introduces competition between regencies/cities. With the gap between 
regencies / cities on the one hand, and faced with competition from business people, financial institutions, and professionals from various countries, without any obstacles. This will weaken or even kill the potential that exists in the area [3].

Each region will try to make it easier to compete with other regions to foreign companies to attract investment. Environmental, security, conservation and quality of life issues can be displaced for the sake of competition. The existence of an integrated market has made the state state basically give up its sovereignty to the free trade regime. These include standardization, quotas, supervision of the quality of goods and services, strict supervision of subsidies, tariffs, taxes and preferences [3].

Each major country has an interest in Indonesia and other ASEAN countries. The problem is how to ensure that ASEAN becomes a sovereign regional organization. Not a tool for the interests of developed countries. Teguh Surya from Walhi, argues that several government programs such as the Master Plan for the Acceleration of Indonesian Economic Development (MP3EI) are made without considering environmental damage. The development of this model still relies on extraction of natural resources [4].

In Act No. 32 of 2009 concerning Management and Protection of the environment emphasizes the concept of sustainable development to ensure the integrity of the environment as well as the safety, ability, welfare, and quality of life of present and future generations. According to Prof. Dr. Emil Salim, The concept of sustainable development, among others, the development process must take place continuously, continuously, and continuously, which is supported by natural resources, environmental quality, and human beings who continue to develop as well. Natural resources (especially air, water and land) have a threshold, where their use will reduce their quantity and quality. The quality of the environment correlates directly with quality of life. The current pattern of using natural resources should not rule out the possibility of choosing other options or options in the future. Sustainable development presupposes transgenerational solidarity, so that the welfare of the current generation does not reduce the possibility for the next generation to improve their welfare [5].

\section{Method}

The method used for this study is the empirical normative legal approach method using secondary data as the main data, namely data obtained by legislation. This research will examinethe effectiveness of Act Number 32 of 2009 concerning Protection and Management of the Environment caused by the Effect of free trade dominance and regional autonomy. The type of research used is descriptive analysis. Descriptive analysis with a qualitative approach.

\section{Result and Discussion}

\section{a. The Effect of Free Trade Domination and Regional Autonomy on the Effectiveness of Act Number 32 of 2009.}

Free trade are ideal trade, where all economic decisions and actions by individuals relating to money, goods and services are voluntary. In the near future Indonesia will face the ASEAN free trade era, Asean Economic Communitty (AEC) or known as the Asean Economic Community (MEA) which will formally open on 31 December 2015. Trade in goods and services is unavoidable due to economic openness and competition that builds the ASEAN economy. In addition, Indonesia will also face the AFTA in 2020 which is a series of similar activities for a larger region, namely Asia [6]. In the free trade, the Indonesian Government boosts various development sectors to improve people's welfare. In this 
development, it will utilize natural resources and other resources that are at risk of causing environmental damage [7].

Talking about the environment cannot be separated from Act number 32 of 2009 concerning Protection and Management of the Environment or often abbreviated as UUPLH. Where in this Law the authority is set between the center and the regions in the protection and management of the environment. In this regulation it is explained that the Government gives broad authority to regional governments which include [8]:

a. Planning aspects carried out through an environmental inventory, determination of the ecological area and preparation of RPPLH (Environmental Protection and Management Plan)

b. Aspects of Natural Resource Utilization carried out based on RPPL

c. Control aspects of pollution and damage to environmental functions which include prevention, mitigation and recovery

d. Environmental maintenance carried out through efforts to conserve natural resources

e. Supervision and law enforcement aspects

According to Act Number 32 of 2004 concerning Regional Government, Regional Autonomy is the right, authority, and obligation of autonomous regions to regulate and manage their own government affairs and the interests of the local community in accordance with the laws and regulations [8].

Regional government, as it regulates and manages government affairs according to the principle of autonomy and co-administration, carries out the broadest possible autonomy, except government affairs which are the affairs of the Government, with the aim of increasing public welfare, public services and regional competitiveness. Regional government in carrying out government affairs has a relationship with the Central Government and with other regional governments including relations of authority, finance, public services, utilization of natural resources, and other resources carried out in a fair and harmonious manner which is regulated by law [9].

Relations in the field of utilization of natural resources and other resources between the Government and regional government include: authority, responsibility, utilization, maintenance, impact control, cultivation, and preservation; profit sharing for the use of natural resources and other resources; and environmental and spatial alignment and land rehabilitation [9].

Implementation of the utilization of natural resources and other resources that are the authority of the regions, cooperation and profit sharing on the utilization of natural resources and other resources between regional governments; and management of joint licensing in the utilization of natural resources and other resources regulated in legislation [9].

Substantially the regions have an important role in preserving the environment. However, in fact the rights and obligations of the region contained in article 21 paragraph 6 of Act Number 32 of 2004 which states that "the regions have the right to get a share of results from the management of natural resources and other resources in the region". Then in order to increase regional original revenue, regions open investment to business actors to invest capital and industrial development in the region. To increase economic growth to advance social welfare. This is what later becomes a gap and an indication of a violation of environmental rules and regulations. Such as the example of the Freeport mining in Papua, coal in Belitung, and other damage on the islands of Java, Sumatra and Kalimantan [10].

Obligations of the regions to find funding sources for governance are often more exploitative. Natural resources owned. Environmental damage seems to occur because the area 
is less careful in giving business licenses to investors. Meanwhile, community compliance with the law does not yet exist [10].

Global warming, which has become a global issue, seems to have not been fully understood by the regional government. The area seemed to close its eyes and allow environmental violations that undermined environmental sustainability because the most important reason was that my region experienced an economic increase and became a rich area. Understanding of the principles of sustainable development has also not been optimally implemented by the regions. Environmental sustainability for future life should be considered by regional governments in the perspective of increasing economic growth and regional development [11].

Natural resources are wealth owned by an area to advance the area. Abundant resources become an economic resource to achieve people's welfare. In this effort, the regional government utilizes the availability of resources to be managed as a source of funding for the implementation of regional autonomy. Environmental damage occurring in the regions clearly violates the Law on environmental protection and management. In this regard, the government actually needs to take alternative steps both concerning the commitment of decision makers in the region and the technical capacity to determine potential and problems in the use of natural resources. One strategic step is to study seriously about regional policies in environmental management. The ideal policy is of course a policy that considers precisely various aspects such as economic growth, social security, ecological vulnerability, and the interests of future generations [12].

The quality of such policies certainly requires adequate quality of human resources. But in fact it is generally known that almost all regions face the same problem, namely about the low competency of human resources to manage a sustainable environment-based economy (suistanable environment). Utilization of natural resources must be balanced with human resources capable of managing natural resources in a planned and wise manner. The availability of abundant natural resources may be a potential for increasing local revenue . However, without being supported by qualified human resources there is no guarantee that the people can prosper [13].

Regional autonomy basically has the potential to trigger environmental conflicts between regions. Commodities of natural resources generally come from an ecosystem area which includes a number of provinces, districts and cities. Therefore, in the implementation of regional autonomy it is necessary to coordinate between regions [14].

So even though there has been dominance in free trade and regional autonomy, the government should always pay attention to Act number 32 of 2009 concerning environmental management and protection so that environmental sustainability is maintained for the safety, ability, welfare and quality of life of present and future generations.

In order for development to be sustainable it requires the following points of wisdom [15]:

a. Management of natural resources needs to be planned in accordance with the carrying capacity of the environment. With regard to environmental conditions (biogeophysical and socio-economic culture), each area built must be in accordance with its zoning zone, such as zones of plantation, agriculture and others. This requires regional spatial planning (RTRW), so that it is expected to be able to avoid the use of space that is not in accordance with the carrying capacity of the environment.

b. Development projects that have a negative impact on the environment need to be controlled through the application of environmental impact analysis (EIA) as part of a 
feasibility study in the project planning process. Through the AMDAL study it can be estimated the negative impacts of development on the environment.

c. Prioritizing the prevention of water, air and soil pollution.

d. Development of biodiversity as a requirement for environmental stability.

e. Development of economic policies that include environmental considerations.

f. Development of community participation, institutions and manpower in environmental management

g. Development of environmental laws that encourage justice to resolve disputes through the application of environmental law

h. Development of foreign cooperation

\section{b. The Relation of Philosophy to Biosentrism, Sustainable Development, Globalization, Privatization and Environmental Damage with the Implementation of Act Number 32 of 2009.}

In accordance with the theory of anthropocentrism that nature is here as a tool for human interests. Even if human beings have the nature of caring for nature, it is solely done to ensure the needs of human life, not because of the consideration that nature has a value to itself that deserves to be protected. Conversely, if nature itself is useless to human interests, nature will be ignored. A good policy and action in relation to the environment will be judged to be good if it has an impact that is beneficial to human interests. Conservation, for example, is only taken seriously as long as it can be proven to have a beneficial impact on human interests, especially economic interests. This kind of theory is also selfish, because it only prioritizes human interests. The interests of other living beings, as well as the whole universe, do not become human moral considerations. Even if it gets moral considerations, once again, those considerations are selfish: in the interests of humans [16].

This anthropocentric perspective causes humans to exploit and drain the universe in order to fulfill their interests and needs, without giving enough attention to the preservation of nature. These exploitative, destructive and indifferent behavioral patterns are considered rooted in a perspective that only emphasizes human interests. This perspective gave birth to greedy and greedy attitudes and behaviors that caused humans to take all their needs from nature without considering their sustainability, because nature was seen as only in the interest of humans. Anything humans can do with nature, insofar as it does not harm human interests, insofar as it does not have an adverse effect on human interests. The human interest referred to here is more short-term. That is the root of various environmental crises [16],[17].

At present we should leave the pattern of anthropocentrism to biosentrism where the universe is a moral community, where every life in this universe, both human and non-human, has moral values. All life in the universe actually forms a moral community. Therefore, the life of any creature deserves serious consideration in every moral decision and action, even apart from the calculation of profit and loss for the benefit of humans [17].

Sustainable development concentrates on three pillars, namely economic, social and environmental development. Sustainable development must be placed as the present and future needs and aspirations of humans. Therefore human rights such as economic, social, cultural, and rights to development can help clarify the direction and orientation of the formulation of the concept of sustainable development [18].

Globalization is a global process where individuals are not bound by the state or regional boundaries. Every individual can be connected by anyone who is in this part of the world and there is a spread of information and communication through worldwide print and electronic 
media [19]. Privatization is the process of transferring ownership from initially managed by the state and public institutions transferred to individual and individual ownership. The transfer of ownership from the public to the individual also results in the transfer of power and benefit of one business. Privatization requires the power and benefits to be owned by individuals [19],[20].

The massive exploitation of natural resources has consequences for the decline in the quality of forest, river, lake, coastal and marine ecosystems caused by activities that do not see long-term consequences, such as forest conversion for HTI, HPH, Transmigration, Plantation, Mining and others. Exploitation also has an impact on the destruction and destruction of species and biodiversity. Mining and logging companies are the most destructive human activities. The right to a healthy environment is violated [21].

Globalization and privatization policies have become a trend in many countries. This concept seems to have bewitched many world leaders to improve their economic order. Globalization and Privatization are considered by them as the answer to the crisis of natural resource management managed by the state. The delivery of natural resources to the private sector is considered by them as an answer to save the expenditure of the state expenditure budget (APBN) and the regional expenditure expenditure budget (APBD) which is sucked up by the production of natural resource management and more functioning for other social responsibilities. As a result, the impact of environmental damage due to exploitation and exploitation is very alarming which has consequences for decreasing the quality of forest, river, lake, coastal, marine and other ecosystems, and encouraging natural disasters in BUMN exploitation and exploration areas and natural resources [22].

For the preservation of environmental problems is very complex and solving the problem requires comprehensive attention and is the responsibility of the government supported by community participation. In Indonesia, environmental management must be based on a clear and comprehensive legal basis so that legal certainty is obtained [23].

The issuance of the Environmental Protection and Management Act (UUPPLH) No. 32 of 2009 replacing the Environmental Management Act (UUPLH) in 1997 which was considered unable to solve environmental problems received much appreciation and as a serious effort from the government in dealing with environmental management issues [8],[23]. Act No. 32 of 2009 also includes a philosophical basis for the concept of sustainable and environmentally sound development in the context of economic development. This is important in national economic development because future environmental issues are increasingly complex and conditions with investment interests. Because the environmental problem is the problem of all of us, both the government, the world of investment and society in general [22],[23].

Based on Act Number 32 of 2009 concerning Protection and Management of the Environment (UUPPLH), protection and management of the environment is a systematic and integrated effort carried out to preserve environmental functions and prevent pollution and / or environmental damage which includes planning, utilization, control, maintenance, supervision and law enforcement. In paragraph 63 paragraph $1 \mathrm{c}-3 \mathrm{c}$ it is stated that the central government to the regions has the authority and duty to establish and implement policies in accordance with the environmental management and protection plan (RPPLH). Besides that in UUPPLH article 65 paragraph 2 and article 70, it is explained about the need to involve the participation of the community in the management and protection of the environment both passively and actively [8]. 


\section{Conclusion}

The dominance of free trade and regional autonomy greatly influences the effectiveness of Act number 32 of 2009 concerning environmental management and protection. Economic growth by relying on the availability of natural resources causes environmental damage and disruption of natural ecosystems. Development carried out so far does not refer to Suistanable Development, which in this case is not in line with the mandate of Act number 32 of 2009 which states that the regions have an obligation to preserve the environment in the area. The shift of the philosophy of anthropocentrism towards the philosophy of biosentrism strongly supports the existence of sustainable development. But globalization, privatization causes exploitation of natural resources which triggers environmental damage.

\section{References}

[1] Amallia, Bella. Dampak Asean Economic Community (AEC) terhadap Tenaga Kerja Indonesia di Singapura. JOM FISIP VOl. 4 No. 2 - Oktober, 2017

[2] Nurhayati, Dies. Dampak Perdagangan Bebas ASEAN terhadap Perekonomian Indonesia. Jurnal Pendidikan Ekonomi, Kewirausahaan, Bisnis, dan Manajemen (JPEKBM) Vol. 1, No. 1, Juli, 2017.

[3] Batubara, Mohamad Yuhdi. Eksistensi Undang-Undang Nomor 32 Tahun 2004 Tentang Pemerintahan Daerah. Jurnal Pendidikan Pancasila dan Kewarganegaraan, Vol. 25, Nomor 1, Pebruari, 2012.

[4] Walhi. Tinjauan Lingkungan Hidup Walhi 2015. Jakarta: WALHI, 2016.

[5] Azis, Iwan,et al. Pembangunan Berkelanjutan: "Perandan Kontribusi Emil Salim". Jakarta: Gramedia, 2010

[6] Inayati, Ratna Shofi.Impelementasi AFTA TantangandanPengaruhnyaterhadap Indonesia. Jurnal Penelitian Politik Vol 7 No 2, 2010.

[7] Nugroho, Wayu dan Surono, Agus. Rekonstruksi Hukum Pembangunan dalam Kebijakan Pengaturan Lingkungan Hidup dan Sumber Daya Alam. Jurnal Hukum Lingkungan Indonesia. Vol 4 No.2 Februari, 2018.

[8] Undang-Undang Nomor 32 Tahun 2009 tentang Perlindungan dan Pemanfaatan Lingkungan Hidup, 2009.

[9] Undang-UndangNomor 32 Tahun 2004 tentang Pemerintahan Daerah, 2004.

[10] Melisa, Gita. Et al. Kendala dan Hambatan dalam Pelaksanaan Penanaman Modal di Kawasan Perdagangan Bebas dan Pelabuhan Bebas Sabang. Syah Kuala Law Journal Vol 1 No 3, Desmber, 2017.

[11] Steni, Bernadinus dan Muhajir Mumu. Perubahan Iklim dan Redd. Jakarta: Huma, 2010.

[12] Tijou Lusiana. Kebijakan Hukum Pengelolaan Lingkungan Hidup di Indonesia. Gorontalo: Fakultas Ilmu Sosial UNG, 2012.

[13] Jazuli, Ahmad. Dinamika Hukum Ligkungan Hidup dan Sumber Daya Manusia dalam Rangka Pembangunan Berkelanjutan. Jurnal Rechts Vinding Vol 4 No 2, Agustus, 2015.

[14] Jauchar B. Otonomi Daerah dan Pengelolaan Sumber Daya Alam di Propinsi Kalimantan Timur. Jurnal Borneo Administrator Volume 8 No. 1, 2012.

[15] Handayani, I Gusti Ayu Ketut Rachmi. Lmplikasi Pelaksanaan Otonomi Daerah Terhadap Kebijakan Hukum Lingkungan. Pranata Hukum Vol 1 No 1 Juli, 2006.

[16] Satmaidi, Edra. Konsep Deep Ecology dalam Pengaturan Hukum Lingkungan. Jurnal Penelitian Hukum Supremasi Hukum. Vol. 24, No. 2, Agustus.

[17] Sutoyo. Paradigma Perlindungan Lingkungan Hidup. ADIL: Jurnal Hukum Vol. 4 No.1.

[18] Runa, I Wayan. Pembangunan Berkelanjutan Berdasarkan Konsep Tri Hita Karana 
Untuk Kegiatan Ekowisata. Jurnal Kajian Bali Volume 02, Nomor 01, April, 2012.

[19] Winarno, Budi Globalisasi Peluang Atau Ancaman. Jakarta: Erlangga, 2008.

[20] Keraf, A Sonny. Etika Lingkungan Hidup. Jakarta: Kompas, 2010.

[21] Asdak, Chay. Kajian Lingkungan Hidup Strategis: Jalan Menuju Pembangunan Berkelanjutan. Yogyakarta: Gajah Mada University Press, 2012.

[22] Sugandhy, Aca dan Hakim, Rustam. Pembangunan Berkelanjutan Berwawasan Lingkungan, Jakarta : Bumi Aksara, 2007.

[23] Siombo, Marhaeni Ria. Hukum Lingkungan dan Pelaksanaan Pembangunan Berkelanjutan. Jakarta: Gramedia, 2011. 